\title{
Fogbél eredetü őssejtek hatása a titánimplantátumok osszeointegrálódására patkány farokcsigolya-modellben
}

\author{
DR. PERCZEL-KOVÁCH KATALIN ERZSÉBET ${ }^{*, * *}$, DR. FARKASDI SÁNDOR* ${ }^{\star}$ KÁLLÓ KAROLA*,****, \\ DR. HEGEDŰS ORSOLYA*, DR. KERÉMI BEÁTA*, DR. CUISINIER FREDERIC***, \\ DR. BLAZSEK JÓZSEF*, DR. VARGA GÁBOR*
}

\begin{abstract}
Az elmúlt évtizedben számos reménykeltő, sikeres kísérlet történt nagyobb kiterjedésű csonthiányok gyógyítására őssejtek alkalmazásával. Az implantátumok osszeointegrációjának őssejtekkel történő elősegítését illető ismereteink ugyanakkor sporadikusak. Kutatócsoportunk számos korábbi munkájában foglalkozott fog eredetű őssejtkultúrák jellemzésével, elsősorban in vitro körülmények között. Emellett patkány farokcsigolyában a közelmúltban kifejlesztettünk egy kvantitatív módon követhető osszeointegrációs modellt. Jelen vizsgálatunk célja volt megismerni, hogy az implantátumok osszeointegrációját hogyan befolyásolják az implantátum és csont közé bejuttatott patkányfog eredú mesenchymalis őssejtek (DPSC) differenciálatlan, illetve oszteogén irányba elődifferenciáltatott állapotban. Eredményeink szerint az implantátum és csont közé beékelődött differenciálatlan pulpasejtek lassítják az implantátum integrációját. Ezzel szemben az oszteogén irányba elődifferenciáltatott DPSC sejtek már nem rontják az osszeointegrációt. Eredményeink arra utalnak, hogy a mesenchymalis őssejtek alkalmazásának sikere nagyban függ az alkalmazás körülményeitől, különösen is a vivőanyagok és oszteogén komponensek együttes alkalmazásától.
\end{abstract}

Kulcsszó: fogbél, patkány, őssejt, implantáció, farokcsigolya, osszeointegráció, differenciálódás, sejtkultúra, szövetépítés

\section{Bevezetés}

A keményszövetek funkcionális helyreállítása komoly kihívás a humán orvoslás területén. A forradalmi áttörés akkor kezdődött, amikor vizsgálatai során PerIngvar Bränemark professzor direkt kapcsolatot tudott kimutatni az alkalmazott titánimplantátum és a csontszövet között, megvalósítva az ideális tartós rögzülést eredményező osszeointegrációt [7]. Bränemark professzor volt az, aki a kellő stabilitást és a hosszú távú optimális funkciót a titánoxid felszínhez közvetlen kötésekkel kapcsolódó csontos rögzüléshez vezette vissza. A két komponens közé ékelődő kötőszövet, vagy egyéb nem csontosodó anyag az implantátum stabilitását csökkenti, majd annak funkcionális elvesztéséhez is vezet. A csavarmenetes implantátum behelyezésekor elért primer mechanikai rögzülés csontátépülés révén szekunder biológia kapcsolattá alakul. Ha augmentációs extra anyag kerül a csontszövet és a titán közé, akkor a szöveti primer kapcsolat gyengül, bár a csont, biológiai átépülése közben erősödik. Így csontképzésnél jelentős mennyiségi előnnyel járhat az augmentáció. Ezzel ellentétesen romlás tapasztalható az implantátum primer rögzülésénél és az osszeointegrációjánál, mely gyengül, és időben elhúzódóvá válik. Exogén mesenchymalis őssejtek adása mellett az hidroxil-apatit augmentáció szervülése javulhat [30]. Az osszeointegráció javítására in vivo mások is eredményesen alkalmaztak fogbél eredetű őssejteket [25].

Kutatócsoportunk korábbi munkáiban részletesen foglalkozott a fogbél és parodontális ligamentum eredetú sejtkultúrák jellemzésével [15, 17, 19, 28]. Emellett a közelmúltban kifejlesztettünk egy csontregenerációs (OSSI) modellt [5], amellyel kvantitatív módon követhető az osszeointegráció folyamata az állcsonthoz sok tekintetben nagyon hasonló farokcsigolyákban. Jelen munkánkban azt vizsgáltuk, hogy a titánimplantátum osszeointegrációját hogyan befolyásolják az implantátum és csont közé bejuttatott fog eredü mesenchymalis őssejtek differenciálatlan és oszteogén irányba diferenciáltatott állapotban. Eredményeink szerint az implantátum és csont közé beékelődő pulpasejtek rontják az implantátum integrációját, és ez a rögzülés lelassulásával jár együtt. Ezzel szemben az oszteogén irányba elődifferenciáltatott sejtek már egy csontképzésre „hangolt” populációt képeznek, így az osszeointegráció nem romlik. 


\section{Vizsgálati anyag és módszerek}

\section{Kísérleti állatok}

A Semmelweis Egyetem NET akreditált állatházából származó Charles River eredetű 350-400 g testsúlyú, Crl(Wi)Br Wistar patkányokat használtunk. Az állatokat a kísérleti periódusban légkondícionált állatházban gondoztuk, életritmusuknak megfelelő fényciklusban, ad libitum folyadék és táplálék biztosításával. A kísérleti anesztéziát intraperitoneálisan adott (ip.) sodium pentobarbital (Nembutal 40 mg/tskg) injekcióval biztosítottuk. A kísérleti periódus végén az állatokat altatásban, az artéria abdominalis átvágásával elvéreztettük. A kísérleti módszer etikai engedélyszáma 1799/003/ 2004.

Fogpulpa eredetú őssejtek izolálása, tenyésztése és oszteogén differenciálása

Felnőtt páciensekből impaktált humán bölcsességfogakat gyűjtöttünk a Semmelweis Egyetem klinikáin. A humán DPSC izolálása és tenyésztése a korábban leírtak alapján történt [15, 18, 19]. Ehhez hasonlóan a korábban leírt izolálási módszereinket alkalmaztuk patkány metszőfog pulpasejtjeinek izolálása során is $[15,17,19]$. Mindkét sejtizolálásnál steril körülmények között dolgoztunk, a pulpakamra feltárása után a mechanikus aprítást ollóval és szikével óra-üvegen végeztük. A kezdő emésztést a-MEM tápoldatban $1 \mathrm{mg} / \mathrm{ml}$ koncentrációjú kollagenáz-I enzimmel végeztük (Sigma) $37^{\circ} \mathrm{C}$-on 1 órán át, 10 percenkénti intenzív rázás (Vortex) mellett. A sejteket $250 \mathrm{~g} \times 5$ perc centrifugálással koncentráltuk. Az üledéket tápoldattal tenyésztőedényekbe mostuk. A sejttenyésztő-tápoldat ( $\alpha$-MEM medium) összetétele a következő volt: $10 \%$-os fetal bovin serum (FBS-Gibco), 2 mM L-glutamin (Sigma), $100 \mu \mathrm{g} / \mathrm{ml}$ streptomycin (Sigma), $100 \mathrm{U} / \mathrm{ml}$ penicillin (Sigma), $50 \mu \mathrm{g} / \mathrm{ml}$ aszkorbinsav-2-foszfát. A sejtek tenyésztése $5 \% \mathrm{CO}_{2}$ standard thermostat gáztér környezetben, $37^{\circ} \mathrm{C}$ hőmérsékleten történt. Tápcsere heti $2 \times$, valamint passzálás hetente $1 \times$ : $0,05 \%$ TripszinEDTA (Gibco) oldattal. Oszteogén-tápoldatot a fogpulpa mesenchymalis őssejtek oszteogén irányú differenciálására használtunk [15, 17, 19]. Az a-MEM tenyésztő médiumot $1 \%$-osra csökkentett FBS-el valamint: $10^{-8} \mathrm{M}$ Dexametazon, $50 \mu \mathrm{g} / \mathrm{ml}$ L-aszkorbinsav-2-foszfát, $10 \mathrm{mM}$ $\beta$-glicerofoszfát anyagokkal egészítettük ki. A sejteket hetente passzáltuk, közben morfológiai változásaikat fáziskontraszt mikroszkópos fényképezéssel rögzítettük. $A$ beültetéshez különböző sejtszámokat használtunk. A beültetés előtt a sejtek vagy nem részesültek előkezelésben, vagy 4 órán át oszteogén médium alkalmazásával végeztük el az elődifferenciáltatásukat.

\section{Patkány farokcsigolya (OSSI-modell) mútéttechnika} Speciális mini implantátumokat használtunk. Grade 3 típusú titán-szálból esztergált-homokfúvott csavarok 1,0 mm mag átmérővel és lapított 2,5 mm átmérőjü fejjel, melyen centrálisan 1,0 mm átmérőjü lyuk szolgál a kitépési erőmérő csatlakoztatására (gyártó: Full-tech Kft.). (1. ábra)

A patkányfarok bőrfelületét vizes lemosással tisztítottuk, majd $3 \times 15$ perces dezinficiáló oldatos (Clarasept-derm, Uniclean Kft., Budapest) áztatással fertőtlenítettük. Vérzéscsillapítás végett a farok tővénél kettős ligatúrát alkalmaztunk a mútét idejére. Steril, egyszerhasználatos takarókendővel történt a mútéti terület izolálása. Állatonként külön-külön sterilizált eszközkészlettel dolgoztunk. A farki 4-5. csigolya ízesülésétől disztálisan 6-8 mm-re körmetszéssel szétválasztottuk a bőrt - ezt kissé visszahúzva -, a csigolyákat egymástól az ízületnél elválasztottuk. A porcfelülettel borított, szabaddá váló csigolyatestet tengely irányban centrálisan 1,0 mm átmérőjü fúróval $8 \mathrm{~mm}$ mélyen előfúrtuk, majd egy következő, 2,0 mm átmérőjű fúróval $5 \mathrm{~mm}$ mély kavitássá tágítottuk. Ez adja a standard határokkal bíró $5 \mathrm{~mm}$ mély $2 \mathrm{~mm}$ átmérőjű csontosodási kazettát (1. ábra). Ez a múvi csontüreg lehetőséget ad a csontosodási folyamat morfológiai nyomon követésére, valamint intraosszeális implantátum in situ behelyezését követően az implantátum osszeointegrációs folyamata biofizikai erőméréssel is vizsgálható. Ugyancsak a csontüreg és az implantátum közötti tér ad lehetőséget különböző vizsgálati anyagok, úgymint sejteket tartalmazó médiumok behelyezésére az osszeointegráció modifikálásának vizsgálatára (1. ábra). A farokcsigolya centrális furatába helyeztük az implantátumot, melyet első harmadában a csontszövet rögzíti. A behelyezés mélységi kontrollját, a stift feje, illetve a rajta lévő furat adta. A fej csavartest felőli válla a furat szélén felfekszik, így centralizálva a csavart annak mélységi standardját is beállítja, melynek kontrollja a fején kialakított furat, amelynek egy síkba kell kerülnie a porcfelszínnel.

A farokbőrt ráhúzva az implantátumra, zsáköltéssel atraumatikusan, de áteresztésmentesen zártuk, a bőrfelületet Braunol oldattal fertőtlenítettük és egy vékony fedőhártyával izoláltuk (Plastubol ${ }^{\circledR}$, methylmethacrylatbutylacrylat-butylmethacrylat, diisooctyl phtalate - Pannonpharma Kft., Magyarország). Az állatokat ébredésig testhőmérsékleten tartottuk. A kísérleti periódus első két hetét az állatok egyedi ketrecekben töltötték, fokozott higiénia biztosításával.

A farok sebgyógyulása után a szocializációs igények helyreállítására visszahelyeztük állatainkat közös csoportjukba, ahol még 6 hétig tartottuk állatainkat. A csontregeneráció vizsgálatára előzetes eredményeink alapján [5] nyolchetes intervallumot választottunk.

A kísérleti csoportok összeállítása a következő volt: valamennyi csoportban azonos körülmények között előkészített patkányfarok osszeointegrációs rendszerben (OSSI modell) a csigolyába fúrt csontosodási kazettába kerültek a 10-10 $\mu$ l-es médiumok, különböző öszszetételben: $B$ csoport sejtmentes $\alpha-M E M$ tápoldat, $C$ csoport 15 ezer patkány DPSC őssejt (kis sejtszám), $D$ csoport 100 ezer DPSC őssejt (nagy sejtszám), E csoport sejtmentes a-MEM oszteogén tápoldat, E2 csoport 


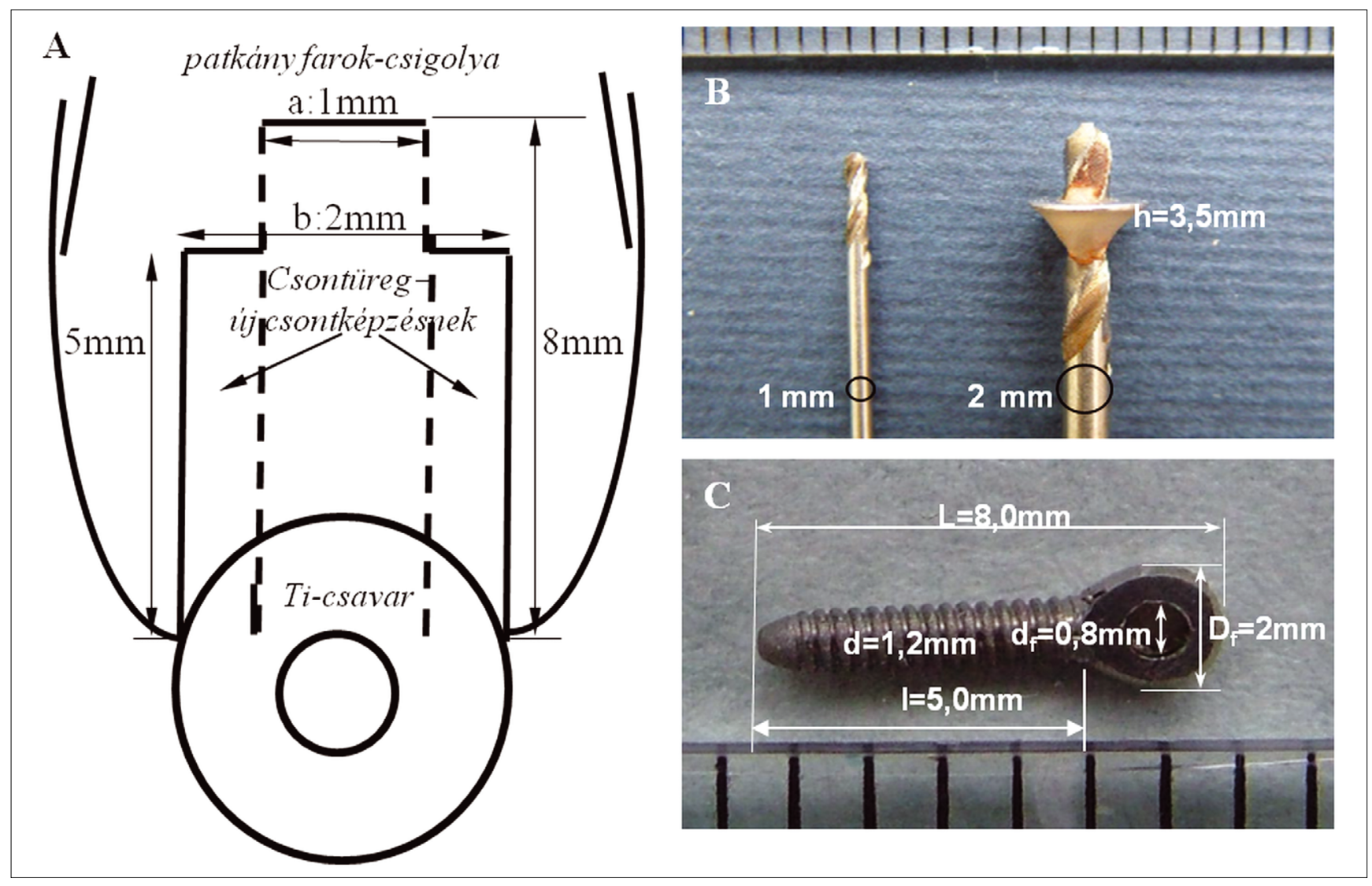

1. ábra: A patkány farokcsigolyába történő implantáció mútéti megoldásai.

A: A csigolya-reparálás sematikus ábrája, feltüntetve az új csont képződésére szolgáló csontüreget,

$B$ : üregformáló eszközök: $1 \mathrm{~mm} \varnothing$ előfúró és $2 \mathrm{~mm} \varnothing$ kazettafúró, mélység korlátozóval, $\quad C$ : Titáncsavar paraméterei.

100 ezer DPSC sejt, 4h oszteogén tápoldatos in vitro elődifferenciációt követően.

A csontkazetta cenrális tengelyébe a médiumok bepipettázása után kerültek behelyezésre az implantátumok.

\section{A Ti-implantátumok rögzülési erejének biomechanikai vizsgálata}

Az implantációt követően 8 hét után biomechanikai vizsgálattal mértük az osszeointegráció előrehaladását. Az elaltatott állatokból 2-2 csigolyát magába foglalóan begyűjtöttük a mintákat. A bőr feltárása után a Ti-stiftek kiszakítási maximum erejének (Newton) mérésével (Tenzi TE 18.1 típusú speciális készülékkel, TENZI Kft., Magyarország) meghatároztuk az osszeointegrációra jellemző rögzülésierő adatokat, melyek iránya a dentális implantátumok terhelésével ellenkező (2. ábra). A mérés menete a következő volt: (1) A csavar disztális végén lévő perforáción átfüzött acélszállal csatlakozunk egy külön erre a célra kifejlesztett digitális végpont-erőmérő müszerrel. (2) A csigolyatest rögzítése és a műszer 0 értékre állítása után csavarmenet előtolással, egyenletes húzóerő fokozással a csavart kimozdítottuk. A múszeren kijelzett maximum érték a rögzülési erővel azonos Newton $(\mathrm{N})$ értéket adta.

\section{Keményszöveti struktúra vizsgálata} és fotódokumentáció

Digitális röntgenfelvételeket a disszekált 3-4. farokcsigolyákról az implantátum kitépése előtt vagy után készítettünk saggitális irányból, arra alkalmas Gendex DENS-O-MAT (KaVo Dental. Gendex Dental Systems) röntgenkészülékkel 65 kV gyorsító feszültség mellett 2,5 sec idejü exponálással. A vizsgálat során a Gendex digitális szenzort rögzítettük, hogy a mintát a szenzorra fektetve, a szenzorra párhuzamosan érkező röntgensugarakkal radiológiai képet kapjunk. A felvételeket archiváltuk. Az elkészített radiológiai képeket egymással összevetettük. A minták makroszkópos képének digitális archiválását mind intakt állapotban, mind a sebészi feltárás után és a kiszakítási mérés után fényképezéssel végeztük, a kísérleti sorszámozás feltüntetésével.

\section{Statisztikai értékelés}

Az ábrákon az eredményeket átlag \pm SEM-ként adtuk meg, az elemszámokat feltüntettük. A kapott vizsgálati erőértékeket a csoportok szerint a jelen felállásban alkalmazható varianciaanalízist követő Bonferroniteszttel értékeltük. 


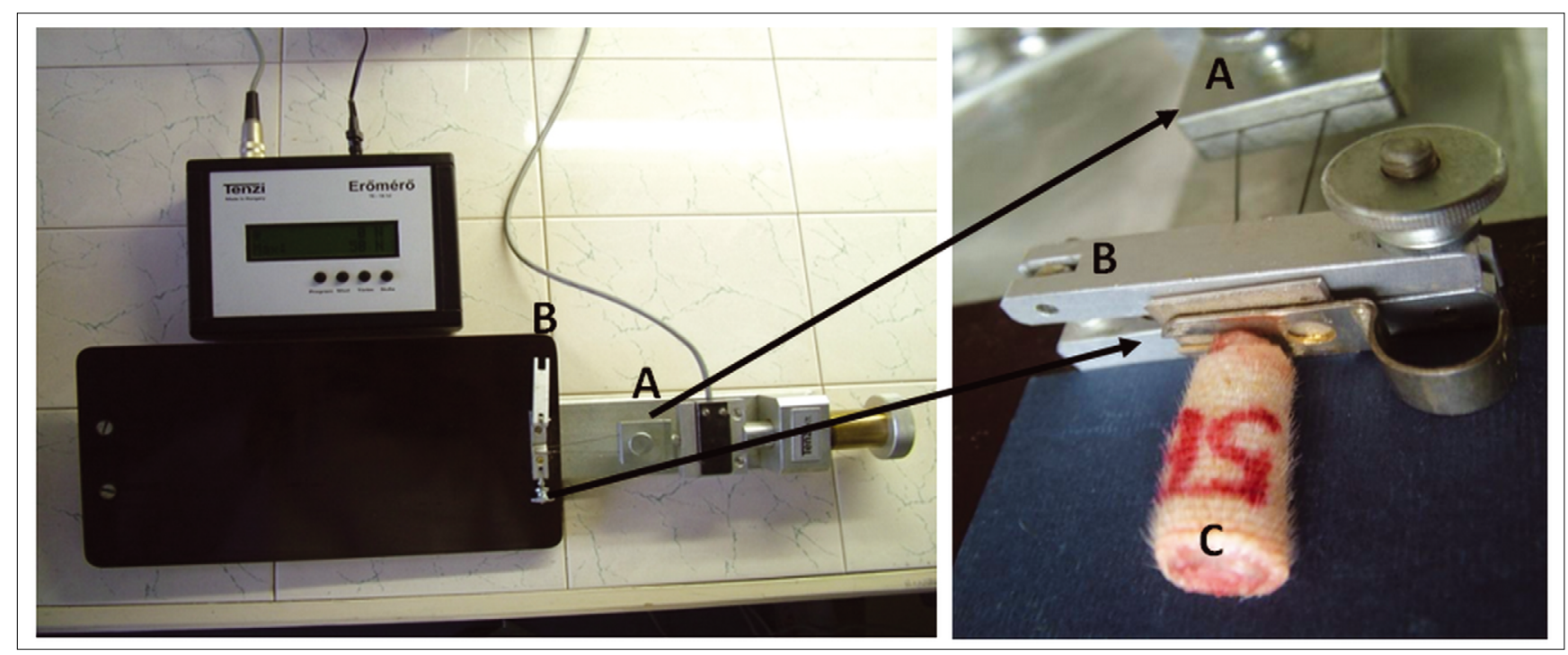

2. ábra: Maximális kitépési erő mérése.

A: Maximum kitépésierő-mérést végző biomechanikai extrakciós egység, speciális fejlesztés a mini implantátumok kimozdítási erejének mérésére (TENZI Kft., Magyarország), B: extrakciós rés és befogó egység, $\quad C$ : szekcionált patkány farokcsigolya
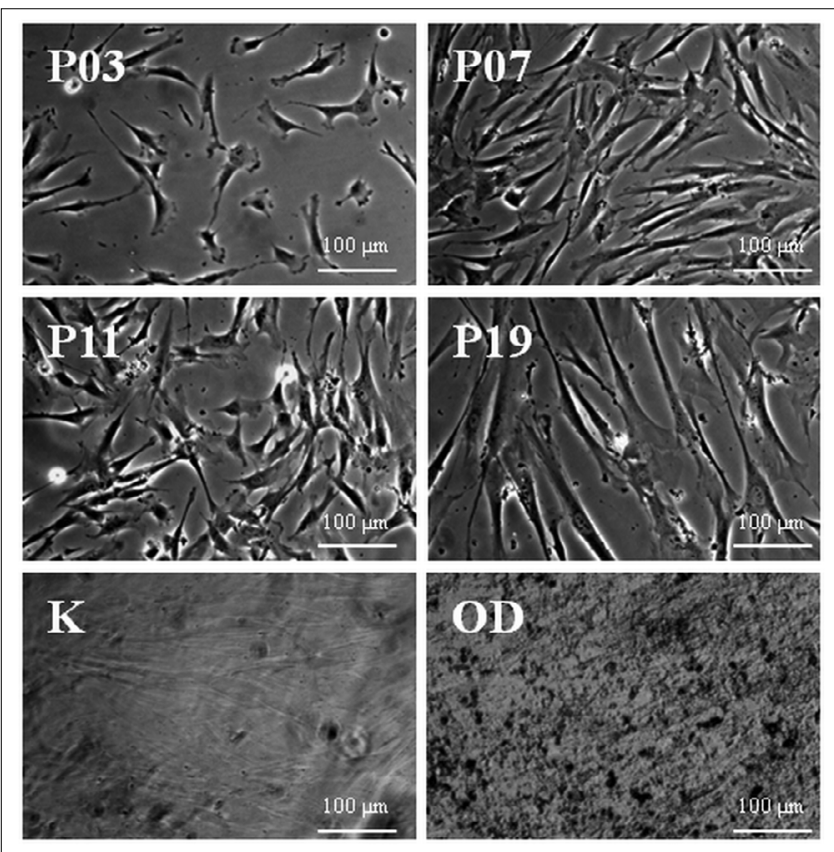

3. ábra: Humán DPSC sejtek in vitro vizsgálata fázis-kontraszt mikroszkóp segítségével.

$A-D$ : a sejtek morfológiája nem változik a passzázsszámmal morfológiájának vizsgálata fázis-kontraszt mikroszkóp segítségével a passzázsszám növekedése folyamán (3, 7, 11 és 19 passzázs).

A tenyészetek tápcseréje hetente kétszer történt,

heti egyszer történt passzázs. A sejtek egészséges, fibroblaszt-szerủ morfológiát mutatnak,

ami a passzázsszám emelésével sem változik. $\mathrm{P}=$ passzázs. $O D$ inszert: Az oszteogén differenciáló médiumban 21 nap után fekete szemcsézettség formájában kalcium depozitok jelennek meg, ami oszteogén aktivitásra utal.

$K$ inszert: A kontrollcsoportban ilyen mineralizációs gócok nem láthatók.

\section{Eredmények}

In vitro vizsgálatok

Az emberi bölcsességfogakból származó DPSC sejtek az izolálást követően várakozásainknak megfelelően 24 órán belül letapadtak a tenyésztőedény felületére, majd osztódásnak indultak. Ezek a primer sejtkultúrák 10 napon belül T25-ös tenyésztőflaskában elérték a konfluens állapotot. Ezt követően hetente passzálva a sejteket a 19. passzázsig jutottunk el, anélkül, hogy a sejtek morfológiája vagy proliferációs képessége megváltozott volna (3. ábra), mindvégig fibroblaszt-szerü morfológiát mutattak. Oszteogén differenciáló médiumban 21 nap inkubáció után jól megfigyelhető fekete szemcsézettség formájában calcium depozitok jelentek meg (OD inszert), ami oszteogén aktivitásra utal. A hasonló módon tartott, de oszteogén indukciós faktorokat nem tartalmazó kontrollcsoportban ilyen mineralizációs gócok nem láthatók (K inszert) (3. ábra). Hasonló eredményeket kaptunk mind a sejtmorfológia, mind a differenciálódási potenciál esetében patkány pulpális sejteken is. $\mathrm{Az}$ in vivo implantációs kísérleteinkhez alacsony paszszázsszámú (P2) tenyészetekből származó DPSC sejteket használtunk fel.

\section{Osszeointegrációs megfigyelések}

Osszeointegrációs vizsgálataink azt mutatják, hogy a sejtekkel nem kezelt esetekben a kitépési erővel jelzett rögzülés jelentős értékeket ért el, akár normál tápoldatot $(41,1 \pm 5,69 \mathrm{~N})$, akár in vitro körülmények oszteogén differenciálódást előidéző médiumot $(46,9 \pm 7,68 \mathrm{~N})$ juttatunk a farokcsigolyán kialakított üregbe az implantátum behelyezése előtt, csakúgy, mint a kis számú 


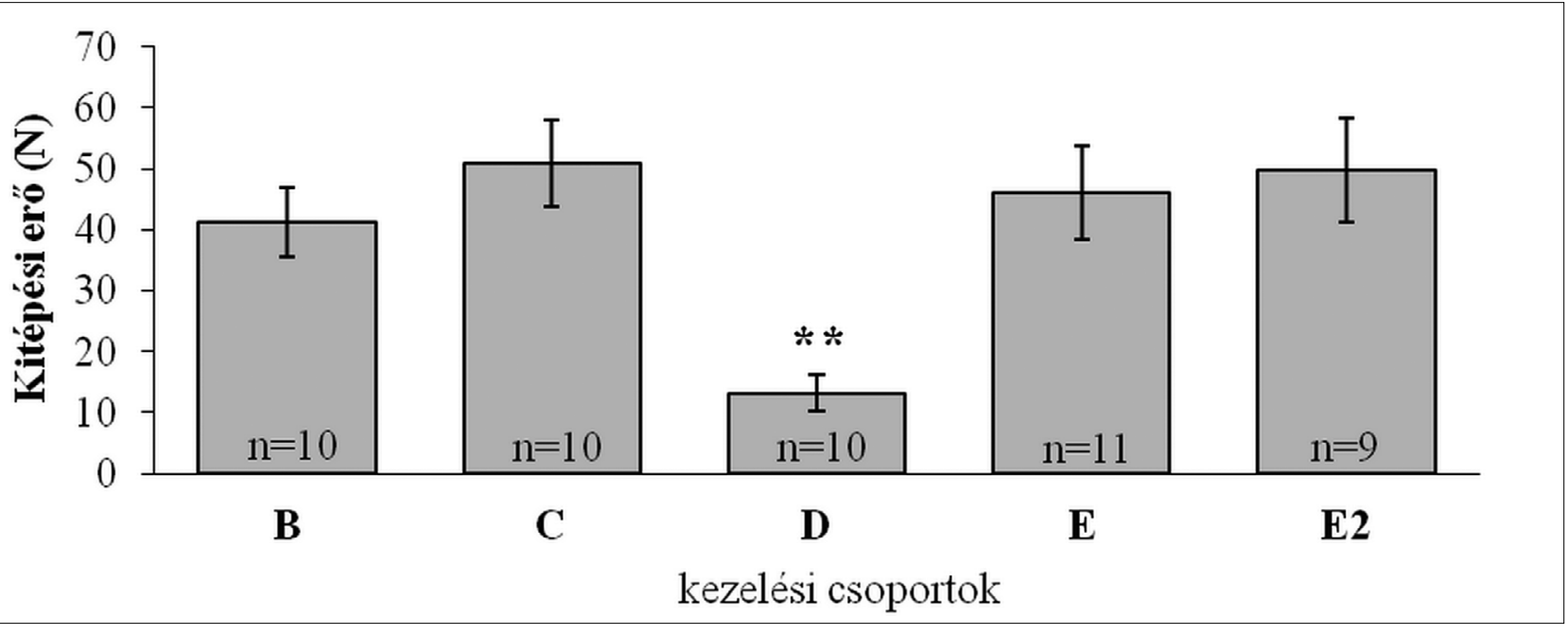

4. ábra: Titánimplantátumok osszeointegrációs rögzülési erejének változása humán DPSC sejtek alkalmazása esetén 8 héttel a beültetés után. $B$ : $\alpha$-MEM sejtmentes tápoldat, $\quad C$ : kis sejtszám (15 ezer DPSC/üreg),

$D$ : nagy sejtszám, nem differenciáltatott sejtekkel (100 ezer DPSC/üreg), E: a-MEM sejtmentes oszteogén tápoldat, E2: 4h a-MEM oszteogén tápban elődifferenciáltatott DPSC, nagy sejtszámban (100 ezer osszeoindukált DPSC/üreg), átlag $\pm \mathrm{SEM},{ }^{* *} \mathrm{p}<0,01$ vs $B$ ( $\alpha-\mathrm{MEM}$ sejtmentes tápoldat).

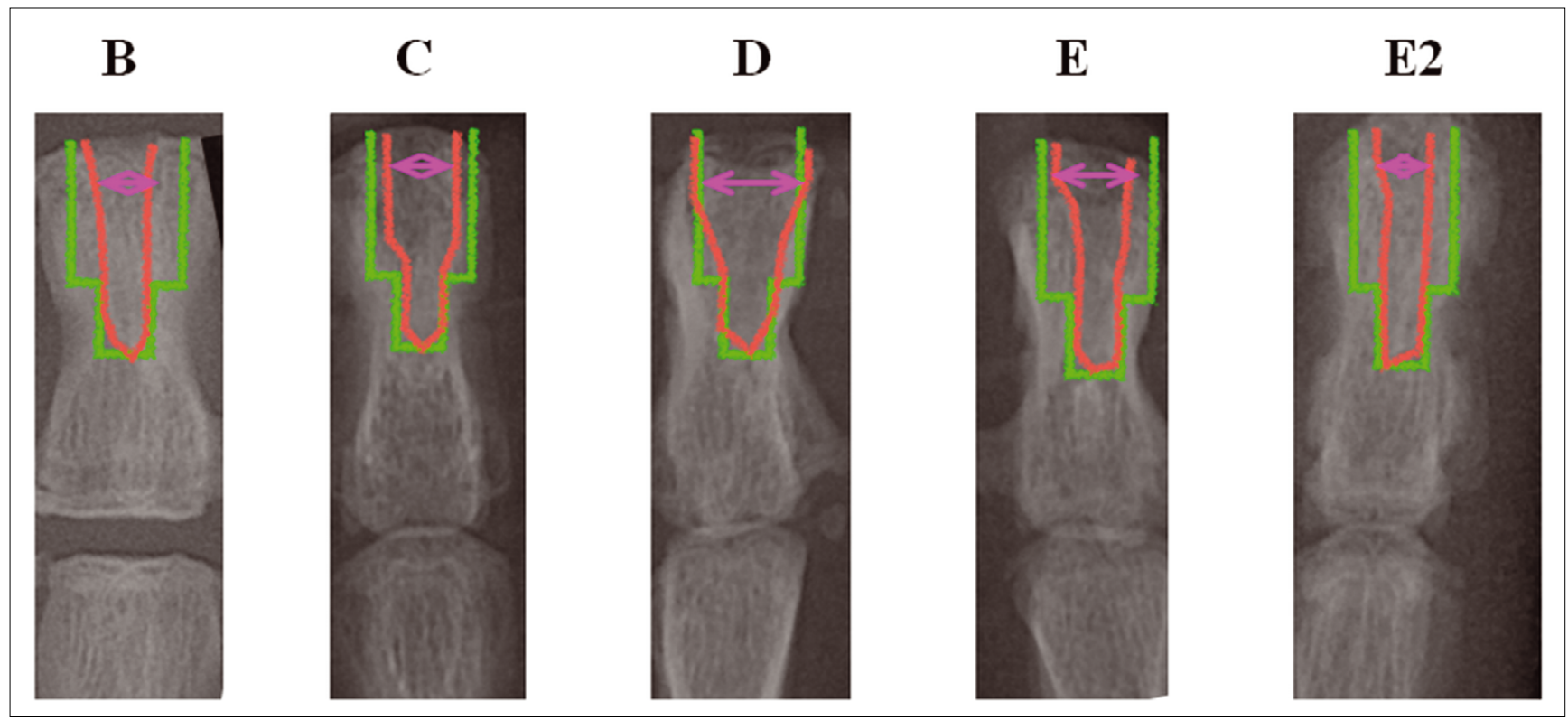

5. ábra: Egyedi röntgenfelvételek az implantátumok stabilitásvizsgálatát követően.

Zöld vonallal jelöltük a sebészeti eljárás során képzett peri-implantális deffektus geometriáját (primer kavitás),

piros vonallal pedig az újonnan képződött csont kiterjedését (szekunder kavitás).

$B$ : A kontrollcsoportban széleskörü új csontképződés ment végbe a csontüregben.

$C$ : Kis DPSC sejtszám injektálása esetén hasonló az eredmény.

$D$ : Nagy DPSC sejtszám alkalmazása esetén nem csak a csontszövet

regenerálási kapacitása csökkent, de lágyszöveti proliferáció is megfigyelhető.

E: Oszteogén elődifferenciáltató médium kontrollképet eredményezett.

E2: Ehhez hasonló képet látunk oszteogén irányba elődifferánciáltatott DPSC sejtek alkalmazása esetén.

(15 ezer DPSC/üreg) nem elődifferenciáltatott sejt beadása mellett $(50,9 \pm 7,19 \mathrm{~N})$. Ugyanakkor a nagy számú nem-differenciáltatott sejt (100 ezer DPSC/üreg) jelenléte jelentősen és szignifikánsan lecsökkentette az osszeointegrációt $(13,22 \pm 3,02$ N). Amennyiben oszteogén differenciáló tápoldattal elődifferenciáltattuk a sejteket a beültetést megelőzően, ez a jelenség elmaradt (4. ábra).

Egyedi felvételek radiológiai elemzése során kapott megfigyelések alapján kijelenthetjük, hogy a nem differenciáltatott sejtek alkalmazása esetén csökken, vagy legalábbis lelassul a csontszövet regenerálódása 
a kontroll kezeléshez és az elődifferenciáltatott sejtek alkalmazásához képest. A lassabb csontszövet-regenerálódás radiológiai képein a primer és a szekunder kavitások összehasonlítása támasztja alá a fent leírtakat (5. ábra).

A patkány farokcsigolyák gyógyulását, gyulladásos állapotát, illetve az implantátumok makroszkópos rögzülését fényképsorozatokkal is rögzítettük. Eredményeink szerint az általunk alkalmazott módszerek következményeként normál gyógyult farokvégeket, a feltárás után gyulladásmentes, konszolidált szövetállományt ta-

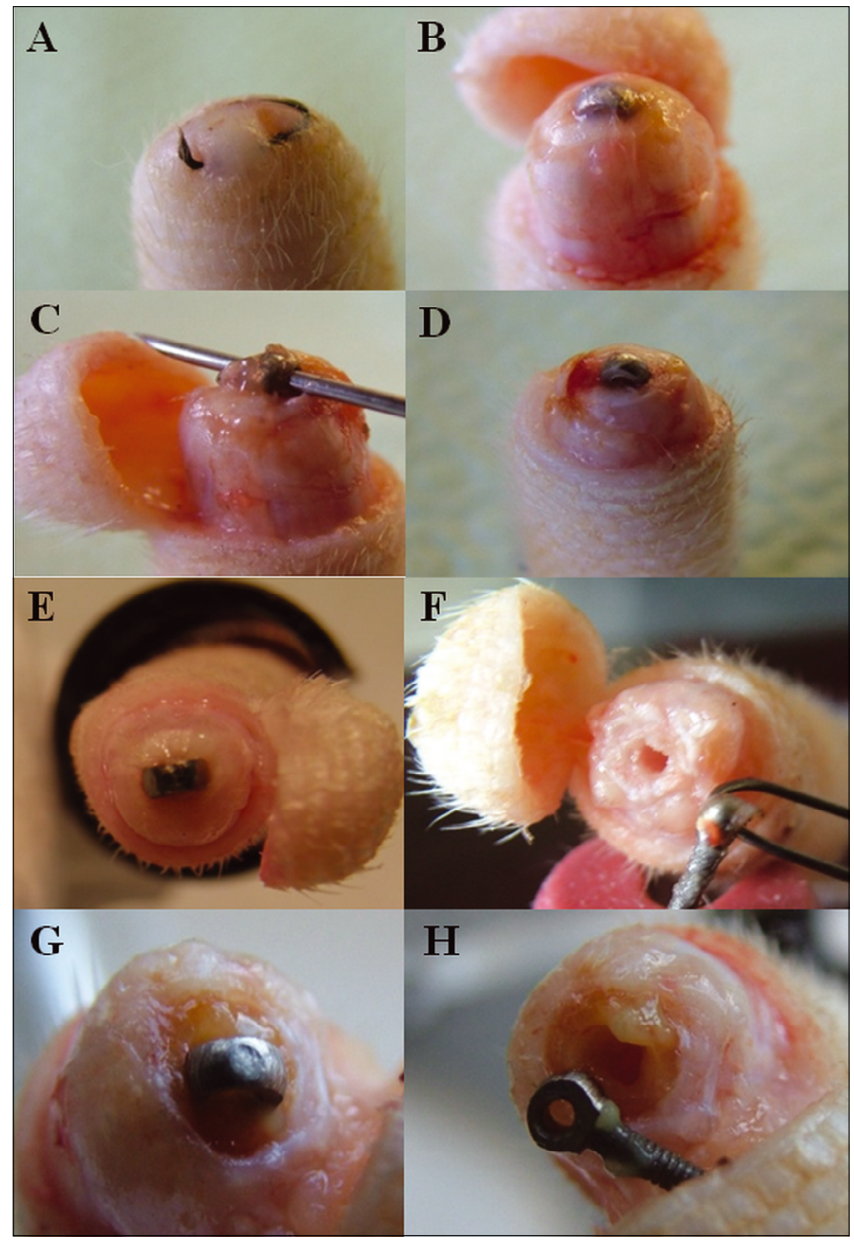

6. ábra: Egyedi titánimplantátumok és farokcsigolyák képe 8 héttel a beültetés után.

A: normál gyógyult farokvég,

$B$ : feltárás utáni gyulladásmentes, konszolidált szövetállomány az implantátum feje körül,

$C, D$ : az implantátumfejben lévő átjárható lyuk, az extrakciós erőmérőhöz történő kapcsolódás céljából.

$E$ : Kontroll, sejtmentes a-MEM médium bevitele nem zavarja az osszeointegráció menetét, az implantátumfej körül kemény csontszövet fejlődik ki.

F: az implantátum kitépése után a regenerációs üregben jól látható a szabaddá váló csontél, ami a 8 hét kísérleti periódus alatt alakult ki.

G: a-MEM médiumban szuszpendált nagyszámú

(100 ezer DPSC/üreg) differenciálatlan DPSC sejt jelenlétében a $2 \mathrm{~mm}$ átmérőjű csontkazettát az implantátumfej körül

lágyszövet tölti ki. A mútéti terület gyógyult, gyulladásmentes.

$H$ : Ugyanabban a mintában az implantátum kitépése után még jobban látható a kissé kocsonyás szövet, amely az implantátumot körülvette. láltunk az implantátumok feje körül. Az implantátumfejben lévő, extrakciós erőmérésre szolgáló lyuk valamennyi esetben átjárható volt (6. ábra). Vizsgálataink szerint a kontroll, sejtmentes a-MEM médium, illetve a differenciálódást elősegítő tápoldat vagy a kis sejtszámú DPSC bevitele nem zavarta az osszeointegráció menetét. Ugyanakkor az a-MEM médiumban szuszpendált nagyszámú differenciálatlan DPSC sejt jelenlétében a kialakított csontkazettát az implantátum-fej körül lágy, kocsonyás állományú szövet töltötte ki. A mütéti terület ebben az esetben is gyógyult és gyulladásmentes volt (6. ábra).

\section{Megbeszélés}

Definíció szerint az őssejtek korlátlan önmegújító képességgel rendelkeznek, és képesek differenciált sejtekké érni. A fejlődési és differenciálódási potenciáljuk alapján megkülönböztetünk totipotens, pluripotens, multipotens és unipotens sejteket, vagy eredetük alapján embrionális, magzati, posztnatális (más néven felnőtt) és indukált őssejt kategóriákat. Az embrionális őssejtek (ESC) nagy közfigyelmet kaptak és technikailag előnyösek a pluripotenciájuk miatt. Az utóbbi időben számos állatkísérlet bizonyította, hogy az ESC sejtek differenciáltatott származékai képesek beteg szövetek funkcionális pótlására, például Parkinson-kór esetében [3], és jelenleg folyamatban vannak olyan klinikai vizsgálatok is, melyekben humán ESC sejteket használnak fel a makuladegenerációk és a gerincvelői sérülések terápiájában [1]. De komoly jogi és etikai kérdések is felmerülnek használatuk kapcsán, továbbá a beültetett ESC sejtek in vivo immunválaszt $[6,10,11]$ és teratómát is indukálhatnak [6].

Jelenleg a regenerációs terápiák számára a felnőtt őssejtek (ASC) közül a legígéretesebbek a mesenchymalis őssejtek (MSC). Ezt a multipotens őssejtcsoportot eredetileg a csontvelöben fedezték fel [2, 26]. Nagyfokú fejlődési rugalmasságuk, azzal együtt, hogy a felnőtt szervezetben is jelen vannak, igen vonzó jelöltté teszi őket a klinikai alkalmazásra. A nagy mennyiségű célszövet létrehozásához viszont még szükség van a standardizált, megbízható differenciáltatási protokollok kifejlesztésére [13, 29]. Amióta felfedezték a MSC sejteket a csontvelőben, hasonló populációkat leírtak más szövetekben is. Ilyen sejteket izoláltak különböző szervekből, többek között csontvelőből, agyból, bőrből, vázizomból és a gyomor-bél rendszerből [14, 20, 21]. Friss kutatások - beleértve a miénket is - kimutatták, hogy jelen vannak az emberi fog pulpájában és a foggyökér hártyájában is [12, 15, 16, 19, 23, 27]. Az MSC sejtek rendkívüli plaszticitására is fény derült. Például míg a csontvelői őssejtek izom-, máj- és idegszövet létrehozásához [4, 8, 9], addig a neurális őssejtek a vér és a vázizom regenerációjához járulhatnak hozzá [4, 8, 9]. E potenciál hasznosításához fontos, hogy további betekintést nyerjünk a MSC sejtek jellemzőibe, 
valamint megvizsgáljuk teljes fejlődési potenciáljukat először in vitro, majd in vivo. Jelen vizsgálataink egyértelműen megerősítik a korábbi megfigyeléseket. Az emberi fogbélből izolált, őssejt tulajdonságokkal is rendelkező kultúránkban legalább 19 passzázsig, átültetésig, a sejtek szaporodási képessége nem csökkent, s ugyanazt a fibroblaszt jellegú morfológiát mutatták, mint az alacsony passzázsszámú tenyészetek, hasonlóan a patkány fogbeléből készült tenyészetekben.

Mivel a fog eredetű őssejtek mesenchymalis eredetű őssejt jellemzőket mutatnak [12, 27], differenciáltatásuk és lehetséges hasznosításuk egyik legkézenfekvőbb irányát a csont jelenti. Valóban, a megfelelő farmakológiai indukció hatására a humán fog eredetű MSC sejtekből in vitro oszteogén/odontogén fenotípusú sejtek differenciáltathatók, melyek polarizált sejttestekkel és mineralizációs gócok felhalmozódásával jellemezhetők [12, 15, 16, 19, 23, 27]. Jelen tanulmányunk is egyértelmúen mutatja, hogy a humán DPSC sejtek in vitro körülmények között, oszteogén irányban könynyen differenciáltathatók, az ilyen módon kezelt kultúrákban 21 napos kezelést követően jelentős mennyiségú minerális depozit figyelhető meg, míg szokványos tenyésztő médium alkalmazásával ez a változás nem történik meg.

A dentális implantátumok széleskörű elterjedésével megnőtt az igény a minél gyorsabb és minél hatékonyabb rögzülést biztosító, jól kontrollálható eljárások iránt. Ebben a tekintetben fontos megfigyelésünk, hogy korábbi vizsgálati eredményeinket [5] megerősítve kimutattuk, a patkány farokcsigolyába ültetett implantátumok jól rögzülnek, s ez a rögzülés a kitépési erő mérésével jól reprodukálhatóan, kis szórással nemcsak minőségi, de mennyiségi tekintetben is jól követhető.

Az őssejtekkel történő szövetregenerációs eljárások sikerei a szervezet különböző szöveti sérüléseinél alkalmazva biztató lehetőségeket vetítenek elő a fogászati implantológia irányában is. Jelen kísérleti felállásban kapott eredményeink között kiemelkedik az az megfigyelés, hogy a nagy mennyiségü, nem-differentált DPSC sejtek nem segítik hanem inkább hátráltatják a titán implantátumok osszeointegrációját ebben a kísérleti modellben. Az a megfigyelésünk viszont biztató, hogy oszteogén elődifferentálással ez a hátráltató tényező kiküszöbölhető. Ez egyúttal azt is jelenti, hogy állatkísérletes modellünkben az oszteogén tényezők egyértelmúen az osszeointegráció elősegítése irányában hatnak. Bár az irodalomban számos megfigyelés fellelhető a DPSC sejtek, fogbél eredetű sejtek csontképződést elősegítő hatása mellett [25, 30], azt is meg kell figyelnünk, hogy ezek a hatások nagy mértékben függenek a sejtforrás fajától, a sejtek állapotától, a bevitt sejtmennyiségtől, illetve a párhuzamosan alkalmazott oszteogén szerkezeti elemek és bioaktív anyagok alkalmazásától [22, 24, 28].

\section{Köszönetnyilvánítás}

Vizsgálataink elvégzéséhez a Magyar-Francia Államközi TÉT-Balaton Program (TÉT_12_FR-2-2014-0010) és az OTKA-NKTH CK80928 kutatási támogatás nyújtott fedezetet.

\section{Irodalom}

1. Aboody K, Capela A, Niazi N, Stern JH, Temple S: Translating stem cell studies to the clinic for cns repair: Current state of the art and the need for a rosetta stone. Neuron 2011; 70: 597-613.

2. Bianco P, Riminucci M, Gronthos S, Robey PG: Bone marrow stromal stem cells: Nature, biology, and potential applications. Stem cells 2001; 19: 180-192.

3. Buorklund LM, Sanchez-Pernaute R, Chung S, Andersson T, Chen IY, McNAUGHT KS és mtsai: Embryonic stem cells develop into functional dopaminergic neurons after transplantation in a parkinson rat model. Proceedings of the National Academy of Sciences of the United States of America 2002; 99: 2344-2349.

4. Buornson CR, Rietze RL, Reynolds bA, Magli MC, Vescovi AL: Turning brain into blood: A hematopoietic fate adopted by adult neural stem cells in vivo. Science 1999; 283: 534-537.

5. Blazsek J, Dobo Nagy C, Blazsek I, Varga R, Vecsei B, Fejerdy P és mtsai: Aminobisphosphonate stimulates bone regeneration and enforces consolidation of titanium implant into a new rat caudal vertebrae model. Pathology oncology research: POR 2009; 15: 567-577.

6. Blum B, Bar-Nur O, Golan-Lev T, Benvenisty N: The anti-apoptotic gene survivin contributes to teratoma formation by human embryonic stem cells. Nature biotechnology 2009; 27: 281-287.

7. Branemark PI, Adell R, Breine U, Hansson BO, Lindstrom J, OhlsSON A: Intra-osseous anchorage of dental prostheses. I. Experimental studies. Scandinavian journal of plastic and reconstructive surgery 1969; 3: 81-100.

8. Clarke Dl, Johansson CB, Wilbertz J, Veress B, Nilsson E, KarlSTROM H és mtsai: Generalized potential of adult neural stem cells. Science 2000; 288: 1660-1663.

9. Galli R, Borello U, Gritti A, Minasi MG, Buornson C, Coletta M és mtsai: Skeletal myogenic potential of human and mouse neural stem cells. Nature neuroscience 2000; 3: 986-991.

10. Grinnemo KH, Kumagai-Braesch M, Mansson-Broberg A, SkottmAN $\mathrm{H}, \mathrm{H}_{A O} \mathrm{X}$, Siddiqui A és mtsai: Human embryonic stem cells are immunogenic in allogeneic and xenogeneic settings. Reproductive biomedicine online 2006; 13: 712-724.

11. Grinnemo KH, Sylven C, Hovatta O, Dellgren G, Corbascio M: Immunogenicity of human embryonic stem cells. Cell and tissue research 2008; 331: 67-78.

12. Gronthos S, Mankani M, Brahim J, Robey PG, ShI S: Postnatal human dental pulp stem cells (dpscs) in vitro and in vivo. Proceedings of the National Academy of Sciences of the United States of America 2000; 97: 13625-1330.

13. Hipp J, Atala A: Sources of stem cells for regenerative medicine. Stem cell reviews 2008; 4: 3-11.

14. Javazon EH, Beggs KJ, Flake AW: Mesenchymal stem cells: Paradoxes of passaging. Experimental hematology 2004; 32: 414425.

15. Kadar K, Kiraly M, Porcsalmy B, Molnar B, Racz GZ, Blazsek J és mtsai: Differentiation potential of stem cells from human dental origin - promise for tissue engineering. Journal of physiology and pharmacology: an official journal of the Polish Physiological Society 2009; 60 Suppl 7: 167-175.

16. Kadar K, Porcsalmy B, Kiraly M, Molnar B, Jobbagy-Ovari G, Somogyı E és mtsai: Humán fogbél eredetű őssejtek izolálása, 
tenyésztése és jellemzése. Fogorvosi Szemle 2009; 102: 175181.

17. Kálló K, Gánti B, Kerémi B, Stiedl P, Nagy Á, Varga G és mtsai: Patkány fogbél eredetű őssejtek tenyésztése és differenciáltatása szövetépítési kutatások megalapozására. Fogorvosi Szemle 2014; 107: 43-49.

18. Kiraly M, Kadar K, Horvathy DB, Nardai P, Racz GZ, Lacza Z és mtsai: Integration of neuronally predifferentiated human dental pulp stem cells into rat brain in vivo. Neurochemistry international 2011; 59: 371-381.

19. Kiraly M, Porcsalmy B, Pataki A, Kadar K, Jelitai M, Molnar B és mtsai: Simultaneous pkc and camp activation induces differentiation of human dental pulp stem cells into functionally active neurons. Neurochemistry international 2009; 55: 323-332.

20. Kuehnle I, Goodell MA: The therapeutic potential of stem cells from adults. Bmj 2002; 325: 372-376.

21. Le Blanc K, Pittenger M: Mesenchymal stem cells: Progress toward promise. Cytotherapy 2005; 7: 36-45.

22. Lu J, Dal J, Wang $X$, Zhang $M$, Zhang $P$, Sun $H$ és mtsai: Effect of fibroblast growth factor 9 on the osteogenic differentiation of bone marrow stromal stem cells and dental pulp stem cells. Molecular medicine reports 2015; 11: 1661-1668.

23. Molnar B, Kadar K, Kiraly M, Porcsalmy B, Somogyi E, Hermann P és mtsai: Emberi foggyökérhártya eredetű őssejtek izolálása, tenyésztése és jellemzése. Fogorvosi Szemle 2008; 101: 155161.

24. Morad G, KheIRI L, KHOJASTeH A: Dental pulp stem cells for in vivo bone regeneration: A systematic review of literature. Archives of oral biology 2013; 58: 1818-1827.

25. Pons C, Panayotov I, Renaud M, Collart Dutilleul P, Yachouh J, CuISINIER F: Osseo-integration potential of dental pulp stem cells spray-deposed on poly-ether-ether-ketone surface for facial reconstruction. Clinical Oral Implants Research 2014; 25: 510.

26. РRоскор DJ: Marrow stromal cells as stem cells for nonhematopoietic tissues. Science 1997; 276: 71-74.

27. Seo BM, Miura M, Gronthos S, Bartold PM, Batouli S, Brahim J és mtsai: Investigation of multipotent postnatal stem cells from human periodontal ligament. Lancet 2004; 364: 149-155.

28. Varga G, Bori E, Kallo K, Nagy K, Tarjan I, Racz GZ: Novel possible pharmaceutical research tools: Stem cells, gene delivery and their combination. Current pharmaceutical design 2013; 19: 133-141.

29. Vemuri MC, Chase LG, RaO MS: Mesenchymal stem cell assays and applications. Methods in molecular biology 2011; 698: 3-8.

30. Xiaohua Y, Zhenuiang Y, Weidong L, Pengcheng X, Sidong C: The non-linear threshold association between aspirin use and esophageal adenocarcinoma: Results of a dose-response meta-analysis. Pharmacoepidemiology and drug safety 2014; 23: 278-284.

Perczel-Kovách Ke, Farkasdi S, Kálló K, Hegedüs O, Kerémi B, Cuisinier F, Blazsek J, Varga G

\section{Effect of stem cells of dental pulp origin on osseointegration of titanium implant in a novel rat vertebra model}

During that last decade a large number of experiments showed the successful application of stem cells in achieving large bone volume regeneration. On the contrary, our knowledge about the promotion of implant osseointegration by stem cell is sporadic. Recently, our research group has carried out an array of studies aiming the characterization of postnatal stem cells of dental origin. In addition, we have developed a novel quantitative model for implant osseointegration in rat tail vertebrae. In the present work we aimed to study how the implant osseointegration process is affected by mesenchymal stem cells of rat dental pulp origin (DPSC) when cells are undifferentiated or predifferentiated into osteogenic direction. Our results show that undifferentiated pulp cells inserted between the implant and the bone slow down the osseointegration process. On the other hand, pre-differentiated DPSCs do not have a similar adverse effect any more. Our data suggest that the success of mesenchymal stem cell application to promote implant osseointegration is highly dependent on the applied conditions, particularly on the parallel application of scaffolds and osteogenic components.

Key words: rat, pulp, stem cell, implant, tail vertebra, osseointegration, differentiation, culture, tissue engineering 